UJBM, Vol. 8, No. 1, January - June 2009, pp 30-34

ISSN 0975-3311 | https://doi.org/10.12725/ujbm.14.4

\title{
RECENT DEVELOPMENTS IN HOUSING AND HOUSING FINANCE
}

\author{
R. Eswaran*, R. Rajeshkumar** \& M. Anandhi***
}

\section{Introduction}

Housing constitutes an important component and a measure of the socioeconomic status of people. It is regarded as a critical sector in terms of policy initiatives and interventions. This is reflected in the efforts of the Government to improve housing and habitat conditions by way of financial allocations in the Five Year Plans and fiscal measures related to housing announced in the Union Budgets.

The reach of the institutional financial market has been extended to serve the housing sector in different regions and different segments of the population. The accessibility of housing finance for people in general has evolved, developed and improved over the years. The financing institutions have come to see good value in funding this component of the economy. With a growing number of players and increased competition, the housing sector is becoming increasingly market-driven. The sector offers safe and

* Department of commerce, KSR College of Arts and Science, Tiruchengode. (TK) - 637 215.

** Research Scholar, KSR College of Arts and Science, Tiruchengode. (TK) - 637215.

*** Research Scholar, KSR College of Arts and Science, Tiruchengode. (TK) - 637215. 
secure residential assets, good business opportunities for the lending agencies and attractive terms for the borrowers. Overall, the affordability of housing loans clearly appears to have improved with fast growing number of borrowers. This has also partly resulted from higher levels of disposable income seen among the earners. There is a felt need for standardization and uniformity in practices among lending institutions in order to improve transparency in the market and bring greater efficiency.

\section{Government Initiatives for housing}

- The National Housing and Habitat Policy were adopted by the Government in 1998 with the main aim of facilitating an investment environment for housing. It was revisited in 2005 accordingly, the Task Force set up by the Ministry of Urban Affairs and Employment submitted its recommendation on Urban Housing and Habitat Policy, suggesting setting up of a National Shelter Fund and Risk Fund with the initial corpus from the Government, to serve the underserved segments.

- Fiscal concessions to individuals increased under Section $80 \mathrm{C}$ of the IT Act [rebate up to Rs I lakh in respect of repayment of principal]. Section 24(2) [interest deduction up to a limit of Rs 1.50 lakh in respect of properties acquired or constructed with borrowed capital and self occupied]

- Two Million Housing Programme which is being monitored annually by the Ministry of Urban Affairs and Poverty Alleviation. This includes credit cum subsidy scheme being undertaken by various State Governments.

- To strengthen the recovery mechanism, Securitization and Reconstruction of Financial Assets and Enforcement of Security Interest Act, 2002 \{SARFAESI Act) was enacted and Housing Finance Institutions ( $\mathrm{HFIs}$ ) included in the eligible list of institutions.

- Selling up of a High level Group to suggest amendments in Securities Act including RMBS for improving liquidity.

- Launching of the Jawahar Lal Nehru National Urban Renewal Mission to facilitate States'/Urban Local bodies to bring necessary amendment in their existing legislation for encouraging increased public and private sector investment for urban infrastructure including housing.

- To improve the habitat conditions in rural areas, construction of 60 lakh houses in rural areas under 'Bharat Nirman' announced. 
- Foreign Direct Investments (FDls) allowed up to 100 percent under the automatic route in townships, housing, built-up infrastructure and construction development projects to catalyze investment in a vital infrastructural sector of the economy.

- A policy was introduced in April, 2000 for setting up of Special Economic Zones $\{$ SEZ) in the country with a view to provide an internationally competitive and hassle free environment for exports. The policy provides for setting up of SEZ's in the public, private, joint sector or by State Governments. In terms of this policy, the SEZs will include inter-alia the facilities like world class residential premises and social services.

\section{RBI's Initiatives for housing}

1. Directions to SCBs to lend at least 3 per cent of their incremental deposif for housing.

2. Housing loans up to Rs. 15 lakhs brought under Priority Sector lending of banks.

3. To provide impetus to rural housing credit, guidelines regarding synchronization of loan repayment installments with the crop cycle, issued.

\section{Housing Finance Developments}

The developments in housing and housing finance activities in recent years reflect the buoyant state of the housing finance market in the country. The multiplier effect of investment in housing has grown over the past years as the proportion of outstanding housing loans as percentage of GDP increased from 3.4 per cent in 2001 to 7.25 per cent by 2007 . This is quite indicative of the potential that exists if the proportion of investment in housing in other developed and emerging economies is considered. The proportion of investment in housing to the Gross Domestic Product (GDP) is 54 per cent in USA, 57 per cent in UK, 40 per cent in the European Union, 17 per cent in Thailand, 34 per cent in Malaysia and 7 per cent in china.

The impact of these positive growth indicators and sentiments has been uniform in the rural and urban areas. The reasons are infrastructural limitations and legal inadequacies coupled with geographical divergences. There has been a growing concern about reaching credit for rural housing 
on market terms and conditions The concerns have been articulated in various policy pronouncements and the sector has to gear up to find market related solutions for them. Investment in housing in the rural areas on a large scale, besides ameliorating living conditions, also impacts the economic profile of the region and can result in all-round development. There is a strong case for a supportive and an enabling policy framework for bringing in large investments in rural housing. This can well change the economic Landscape of rural India.

\section{Housing Loan Product by Primary Lending Institutions}

Primary lending institutions (PLIs) i.e. Scheduled Commercial Banks (SCBs), Housing Finance Companies [HFCs], and Apex Co-operative Housing Finance Societies, (ACHFS) are offering various housing loan products which include:

a. Home Loans for construction including purchase of land/acquisition of new house built in flats.

b. Home improvement Loans for repairs, renovation

c. Home Extension Loans for upgradation of existing houses.

d. Home Equity Loans.

e. Finance to public and private builders lo increase the supply of land suitable for building houses.

f. Financing for housing to Self Help Groups (SHGs)/ Micro Financing Institutions (MFIS).

\section{Conclusion}

The facilitating role of the government and other financial institutions along with private intervention in facilitating finance to address the housing needs of the society is an indication of the significance of the sector in overall development of the economy. The National Agenda for Governance which envisages the construction of 2 million dwelling units every year, also emphasizes that housing activity would be an engine for substantial 
generation of employment in the country. To this end, efforts are being made identity the legal and administrative impediments and addressing them suitably. The earlier dependence on the public agencies is now slowly giving way to create a strong Public - Private partnership for tackling the housing and habitat issues. The Government's intervention will be limited through fiscal concessions, legal and regulatory reforms and creating an enabling environment while the private sector as the other partner would be encouraged to take up land assembly, housing construction and invest in infrastructure services. Now a days private sector banks are leading institutions in housing finance.

\section{References}

1. Management of Indian financial institutions. R.M Srivastava\&Divya nigam Himalaya publishing house-2008

2. Financial services-B.Santhanam. Margam publications-2007

3. Economy survey 2007-2008, Gol, oxford university press.

4. www.nhb.org

5. www.housingfinance.com 